\title{
Especially Loved by Allah: Muslim and LGBTQ in Istanbul
}

\author{
ANN af BURÉN \\ Södertörn University
}

\begin{abstract}
The article builds on ethnographic fieldwork within the LGBTQ (Lesbian, Gay, Bisexual, Trans and Queer) milieu of Istanbul. It is based on material collected through participant observation and semi-structured interviews with people who at the same time selfidentify as practicing Muslims and have romantic and sexual relations with people of their own sex. The protagonist of the article is a pious Muslim woman who can be placed in the category of LGBTQ Muslims who do not seek coherence and are not involved in a reinterpretation of their Islamic tradition. The article explores the complex ways in which this woman handles the potential conflicts between her sex life and her religious beliefs, and points specifically to the way she supports herself on the firm belief that Allah loves and protects her.
\end{abstract}

Keywords: Islam, homosexuality, Turkey, gender, identity, queer, LGBTQ, religion

When Çiçek leaned towards me and in a secretive voice told me that she was in fact one of God's specially loved ones, 'Allahin sevdigi kuluymussum', I was not as surprised as I was the first time I heard the expression in this context. But I was equally pleased, as I felt it to be refreshingly subversive, in a completely non-intentional way.

In this article, my purpose is to contribute to the growing body of work in LGBTQ $^{1}$ (Lesbian, Gay, Bisexual, Trans and Queer) religious studies, ${ }^{2}$ as well as more specifically to the field of Islam and same-sex sexualities. Here I explore the lived experiences of Çiçek - a woman who identifies herself first of all as a practicing Muslim and secondly as a heterosexual

1 This acronym is widely used as an overarching category, although the terms included are contingent, over-lapping and interrelated and even contested. It should be clear that the category contains both diversity and commonality and that it should not be seen as a homogeneous group. 'Queer' is a widely debated concept that in this article is used to refer to people that fall outside the norm in terms of sexuality and/or gender expressions.

2 For an overview of this field, see Wilcox 2007. 
woman, even as she has sexual and romantic relations with women. The study is based on data collected during the first half of 2007, when I carried out fieldwork within the LGBTQ milieu of Istanbul. During this period I engaged in extensive participant observation, which meant spending time at bars, clubs, cafés, and in private homes. In addition, I performed twelve semi-structured, in-depth interviews, a majority with women and male to female $(\mathrm{mtf})$ transwomen between twenty and forty years of age. They all identified as practicing Muslim. Çiçek was one of the people I was especially intrigued by, and her example pinpoints certain recurrent trends in the narratives of my informants.

Research done on Muslims who either have an LGBTQ identity or who give expression to some kind of same-sex desire or alternative gender expression has tended to focus on those who seek coherence (Yip 2004; 2005; 2008a; Bereket \& Adams 2006; Rouhani 2007; Abraham 2009; Yip \& Khalid 2010). In my fieldwork, however, this is not the group that is most sharply foregrounded: a more frequent goal among my respondents, particularly the interviewees, is to find ways to live with paradox, ambiguity and contradiction, rather than to actively seek to reconcile the different aspects of their lived reality.

Accessing this field is of course not without its challenges. Homosexuality and trans identities are stigmatized and there is widespread discrimination against visible LGBTQ people throughout Turkish society; however, in the Taksim area of Istanbul, where most of the fieldwork was performed, perhaps less blatantly so. Nonetheless, speaking openly about non-heterosexuality and non-heteronormative expressions may endanger the participants in various ways. It may for example cost them at the social level, in terms of social exclusion in a society where the individual has strong bonds to family and neighborhood.

While neither homosexuality nor sex-changes are illegal in Turkey, there are no laws specifically protecting these groups. For example, LGBTQ people are not mentioned in the anti-discrimination act, or in relation to hate crimes. In fact, LGBTQ organizations and businesses are often targeted on the basis of morality laws. Apart from the need for discretion that follows from such a hostile climate, there is also, as in all fieldwork, the question of establishing the trust of the informants. In order to gain this confidence, I chose to be open about my personal history when asked. Being openly non-heterosexual was something that turned out to be pivotal for the data collection process: it positioned me as an 'insider' in terms of sexual identity. I found that this opened up doors to people who would, at least initially, 
be hesitant to share information regarding their sexual lives with someone who did not share this experience.

Another crucial aspect of my information gathering was finding other gatekeepers than the politically active within LGBTQ organizations. ${ }^{3}$ It was through their help, and snowballing, that I was able to reach also those normally reluctant to associate with the LGBTQ community as such.

Moreover, being a woman was important in order to gain access to female-dominated queer spaces. ${ }^{4}$ Many of the 'gay-friendly' bars and cafés in Istanbul have a mixed clientele, although at that particular time, the spring of 2007, there were several bars dominated by a female clientele as well as one lesbian nightclub.

On the other hand, as a non-Muslim Swede I remained an outsider on a cultural and religious level. This gave me the advantage of being viewed as someone who was in need of illuminating explanations, as I in fact often was. The positionality of the researcher and the methodological, epistemological, and ethical implications of the insider-outsider dynamic naturally deserve more elaboration than space allows here. These issues, with regard to research on sexual minorities and sensitive material, have been interestingly explored by the sociologist of religion Andrew K. Yip, who has published extensively within the area of religion and same-sex sexualities (Yip 2008b).

In this article I adopt a hermeneutic approach to the material, in the effort to interpret Çiçek's self-understanding and her ways of dealing with the apparent discrepancies between her interpretation of Islam and the way religion is expressed in, and governs, her everyday life. I do so in the light of her understanding of sexuality, and discuss ways in which her example has challenged my own cultural understanding of such concepts as sex, gender and sexuality. Where I find it fruitful I try to make my biases explicit, since they were in fact a steppingstone for the knowledge produced through this study.

\section{Çiçek}

One of the first times I met Çiçek was in a bar. When I explained that I was doing fieldwork on the topic of Islam and sexualities, she said, with firm-

3 In 2007 Lambdaistanbul was still the prominent LGBTQ organization, even though in that same year another one was founded, with a more specific focus on trans issues, Istanbul LGBTT.

4 By 'queer spaces' I refer to situations and physical places, as well as to internet forums, that are produced by LGBTQ people, naturally all contested, temporal, and dynamic. 
ness in her voice and pride in her eyes and shoulders, 'then you should talk to me. You will find no one else who has thought about this as much as I have.' After that we hung out in 'gay-friendly' cafés and bars in Beoyğlu, central Istanbul, on many occasions in the course of my fieldwork. On one occasion we met with an interpreter, and mutual friend, for a two-hourlong, semi-structured interview, from which many of the quotations in this article are derived.

Çiçek lives with her parents, brothers and sisters, on the Asian side of Istanbul. She is a central figure in the household, partly because she earns more money than the rest of the family and this gives her a certain stature, but mainly because she is the one of those dominant Turkish women that are able to fill a room with their loud, warm presence. Her family knows nothing of her sexual and romantic dealings with women. She is 34 years old, outgoing, and as I said, a rather dominant character who is proud to be Turkish. Her gaze is at the same time stern and full of laughter. She has shoulder-length dark hair; her make-up is usually natural-looking, accentuating the eyes. She naturally dresses differently depending on where one meets her, but she tends to go with blue jeans and a blouse.

In the beginning of our acquaintance, I could not help thinking that Çiçek seemed to fit the category 'lesbian': she had never expressed any desire towards men, but very much so towards women. However, I soon learned that she would take that as an insult. Once, when (in my ignorance) I pressured her to categorize herself, she reluctantly labeled herself as bisexual, but quickly asserted that actually she is 'heteroseksuel'; or at least, as she put it, she will be so when she eventually marries a man. It seems as if she feels no need to claim bisexuality as a constant sexual identity. For her it is possible to go in and out of my sexual identity categories, if she uses them at all. From my perspective Çiçek could be considered queer, in the sense that she challenges the normative 'western' understanding of sexual categories and notion of heterosexuality. But she would hate that categorization as well. And she is right, of course, to refute my attempts to categorize her as someone different from the norm. What is queer depends on the context; it depends on whom you ask, when you ask it, and what you ask about. To fall outside of the norm is a matter of perspective. ${ }^{5}$ In my own context her example would be subversive, since she challenges my notion of the category 'heterosexual'. From her perspective, however, the situation is quite the contrary.

5 Compare Ambjörnsson 2006, 96. 


\section{Context}

In discussing attitudes towards same-sex oriented desire and behavior, I believe it important to glance towards postcolonial critical analyses. These urge us to be sensitive to the possibility that a representation of 'nonwestern' states, such as Turkey, ${ }^{6}$ as lacking in human rights concerning sexual orientation and gender identity, can, if framed in overly simplistic terms and based on the argument of a universalistic notion of sexuality and gender, be seen as an expression of orientalism or global racism. On the other hand, depicting Muslim countries as having a 'homosex'-friendly past would not only be generalizing but also a gross overstatement. In addition, the mere intention of looking at a univocal past is in itself problematic, since it presupposes an essentialist view both of cultures and traditions and of human sexuality.

However, while an essentialist perspective may be problematic at a theoretical level, it is still relevant for many within the LGBTQ community in Turkey, at least at the level of discourse. The idea of a historical continuum, wherein the term homosexuality is new but the concept is not, plays an important part for many of the activists that I have spoken to. Certainly for many trans people, who frequently refer to the Ottoman history when speaking about themselves. A major concern within activist organizations is to distance themselves from the idea that LGBTQ identities and rights are 'western notions', since such a connection would lead to further stigmatization of same-sex sexualities in Turkey, and would therefore be counterproductive for their cause. They emphasize theirs as a local identity, in order to firmly establish themselves within their own context and contest accusations that their sexualities are a result of 'western decadence'.

In contemporary Istanbul we find at this moment a great variety of expressions of this area's specific sexual history. Murray and Roscoe suggest that same-sex sexual patterns are neither unequivocal nor obvious: 'What might be termed "pre-modern", "modern" and "post-modern" homosexualities actually co-exist in contemporary societies, Western and nonWestern' (Murray \& Roscoe 1997, 313). This means that different views on

\footnotetext{
6 Although the question whether Turkey is or is not part of what is broadly termed 'the west' is part of an ongoing discussion, for the sake of argument I refer to it in this section as 'non-western'. At least Turkey does not have an undisputable place within the frames of this fuzzy concept. Nonetheless, as illustrated by its geographical location as a bridge between Europe and Asia, Turkey is not separated from 'western' societies and the concepts that have developed there. There is a longstanding tradition of intercultural meetings, cultural appropriation, and reinterpretation in both directions - processes that are naturally also reflected among groups of sexual minorities.
} 
'homosexuality' flourish simultaneously: that is to say, different discourses and paradigms co-exist. This is naturally also the case in today's Istanbul, where we find different understandings of what it entails to be engaged in same-sex sexual relations.

Based on from my material, I consider it possible to divide these into two general categories. Perhaps needless to say, these are neither fixed nor homogeneous. There are Muslims in both these camps and people within them use different sorts of strategies to cope with the apparent contradiction between standing in a normatively transphobic and homophobic tradition and the lived reality of having same-sex sexual relations or a trans identity.

Firstly, we have people who exemplify an 'otherness', i.e. people who diverge from normative notions of sexuality. This is a group that is gradually becoming more visible in Turkish society, mostly through the work of the different LGBTQ organizations located in the larger cities (e.g. Lambdaistanbul, Istanbul LGBTT and Kaos GL), who are lobbying for LGBTQ rights at different levels of society. As an example, we have the gey identity described by the sociologists Bereket and Adams (2006). They discuss the effects of globalization in relation to the development of a local gey identity, among men who have sex with men, in Turkey. ${ }^{7}$ They show that identifying as gey is not necessarily a result of pressure from outside, but should be seen as a hybrid identity, which can be expressed in many different ways. The identity of gey is perceived as both local and global.

Apart from these glocalized ${ }^{8}$ variants of sexual categories, other identities, concepts, and norms within Turkish society are constantly recreated and reinterpreted. There are people, such as Çiçek, who do not identify themselves as belonging to any category deviant from a heterosexual norm, even though they engage in same-sex sexual activities. These individuals constitute a category which may be connected to what scholars have shown to be a common pattern in the sexual history of Muslim countries. The American sociologist and anthropologist Stephen O. Murray argues, in his article 'The Will Not to Know - Islamic Accommodations of Male Homosexuality', that in Muslim countries, before the emergence of Islamism, same-sex oriented desire and behavior have been censured rather than seen as something that needed to be eliminated (Murray 1997, 14ff). The American scholar of religion Kecia Ali in turn sees this strategy as 'part and parcel of general insistence on not attempting to pursue potentially

7 Actually, the term gey is according to my material also frequently used by women to identify themselves.

8 With reference to the term 'glocalization', launched in the 1990s by Roland Robertson. 
indiscriminating information about one's fellow Muslims or to disclose it about oneself' (Ali 2006, 85).

Between the two categories described above, glocalized sexual identities and traditional/cultural sexual patterns, there is a notable tension, at least in one direction: a tension that very much regards the question of visibility versus invisibility, diametrically opposite requisites for the existence of each group. Çiçek is one of the many who do not welcome visible expressions of same-sex desire or alternative gender expressions, or the work engaged in by LGBTQ organizations. On several occasions, I have sat in on discussions about the reasons for example, why one should not go to a party organized by Lambdaistanbul. 'The money goes to them and they only work for themselves', Çiçek said once when the issue came up. I found it strange at the time, since Lambdaistanbul's activities, aimed at raising awareness and ending discrimination against LGBTQ people, rest almost entirely on voluntary work; its members have diverse backgrounds and affiliations. Nonetheless, even when I pointed this out, Çiçek insisted that they do nothing for her. It seems as though Çiçek believes that 'open' LGBTQ people, with their visibility agenda, are harming her possibilities of living out her desires, which rely on not necessarily identifying with or at least not speaking about same-sex sexual acts and desires. I believe that, apart from a general skepticism towards NGOs and government, this is an example of the disparities in the agendas of these two groups.

\section{Am a Woman - Therefore I Am Heterosexual}

Since I was born and raised in Sweden, the need for a perspectival approach towards concepts was a lesson learnt in Istanbul over and over again. This is certainly not something which is limited to geographical or cultural differences, but it was highlighted for me in this context. I was reminded that categories of sexual identity are polysemic and culturally, socially and historically positioned - but also that the notion of sexuality is contextually bound. Not everyone has the same understanding and claims as to what sex and sexuality is and entails. At an empirical level, the meaning of a word or concept depends on how it is used in a specific context. Specifically, through the narratives of my interviewees, I have been forced to revisit and to some extent reevaluate the term 'heterosexuality'.

At the root of Çiçek's reasoning when it comes to sexuality lies an understanding of heterosexuality as linked to biological sex, and of homosexuality with sidestepping or challenging biological sex, which for Çiçek is provoca- 
tive and 'unnatural'. Çiçek lives in a rigid sexual dichotomy, that of man and woman, which for her is perceived as a religiously motivated order. It is also in line with the dominant view of gender and sexuality among Muslims, which emphasizes the complementarity and unity of the sexes (compare e.g. Boudhiba 1998; Green \& Numrich 2001). This dichotomy, according to Çiçek, should under no circumstances be challenged. ${ }^{9}$ This attachment to a two-sexed duality seems, for people like Çiçek, to dictate their opinions on taste and action. For example, Çiçek shows little understanding as to why a woman would want to appear masculine: 'they act like men', she says, as if this were something particularly despicable. She herself is attracted to other heterosexual, feminine-looking women, she says - not to women who look or act masculine: 'not to their sexuality, personality, how they look, nothing'. She upholds an idea of womanhood as 'God-given' and thus professes to an essentialist construction of femininity based on religious conviction. She finds masculine women and effeminate men provoking and problematic, and would rather not be seen with them. A 'straight-looking' person who has a sexual relationship with someone of his/her own sex, like Çiçek herself, is not perceived as a challenge to the two-sexed system. Problematic people are those who do not perform their sex in a normative way.

Thus, for Çiçek it seems to be more important to perform one's biological sex in an unambiguous way than to have specifically opposite-sex sexual relations. As long as she looks like a woman she is heterosexual, because it would be an impossibility not to be. This way of thinking regarding gender and sexuality opens up different strategies for relating to both one's own identity and one's sexual practices. It is as though her religious conviction governs other aspects of her identity, such as gender identity and expression and sexual identity.

In the next section of this article, I discuss three particularly striking and interesting strategies used by Çiçek in dealing with being a practicing Muslim and at the same time having same-sex sexual relations: 1) living with inconsistency, 2) splitting off different spheres of life, and 3) religious individualism.

\section{Living with Inconsistency}

When we met for the in-depth interview, Çiçek immediately told me that being LGBTQ and Muslim are entirely contradictory. '[They] cannot live in

9 An awareness of intersexual people, born outside of this norm, is blatantly absent in this context - as something not unthinkable but perhaps unthought-of. 
harmony', she said in the decisive way she delivers every statement. This standpoint was curious to me, in that Çiçek stands out as an example of a person who is actually carving out her own space through a continuous process of negotiation between areas that at first glance seem irreconcilable. Her example in a way implies that in practice, living in a same-sex relationship and being a practicing Muslim are less incompatible than in theory would seem to be the case. Nonetheless, her own understanding of her situation reflects the standard answer among Muslims in Turkey, rather than mine, according to which she is an active part of a continuous process of religious change and innovation. Again, our different ways of defining concepts give us different answers and interpretations. She identifies with the norm and not the exception, and is thus able to condemn this particular combination of religious and sexual identities.

When we turn to the specifics of her everyday experience, however, reality is not so easily translated into theory and generalizations. For Çiçek, as for most people, different strands of thought and patterns of behavior come together and give rise to contradictory experiences. Her way of dealing with these incoherencies and contradictions is particularly interesting.

With regard to her actions, Çiçek expresses two disparate views as to the 'sinfulness' of homosexual behavior. On the one hand, she believes that whatever she feels it is through God - even her relations with women. She believes that God would never want her to have relationships with women, but she also believes that 'if God did not want it, God would stop it. God made me feel this way'. Thus she subscribes to an essentialist understanding of being 'born this way'. This line of argument is of course not unique to Çiçek. To take an essentialist stand and apply what British sociologist Andrew K. Yip calls 'ontogeneric arguments' (Yip 2004, 299) is frequent among people within the movement for queer-friendly interpretations of Islam, and for devout Muslims who try to reconcile their faith with their same-sex desires. ${ }^{10}$

On the other hand, she says that 'what I am doing and what I am feeling towards other women is a sin'. Here she seems to be speaking from the perspective of institutionalized religion. In this line of argument, she makes the point that it is by her own choice that she engages in these relations. 'Because no one is forcing you to do anything. If it is in you, the only thing you need is somebody to arouse these feelings.' Accordingly, she says that when she 'passes to the other side' she will be punished for her sins. Not

10 This is further explored by Samar Habib (2008), see also af Burén (2006-2007). 
only for being with women, however, but also for many other things that she has done.

These two parallel understandings of Çiçek's behavior puzzled me at the time of the interview, and I repeatedly tried to get her to clarify for me how these two paradoxical views related to each other. In the end she impatiently concluded the discussion with the phrase, for me still somewhat enigmatic: 'I do what I do and I also do what God wants me to do'. There are of course different possible interpretations of this paradox. One possible explanation is that what she was trying to communicate was the simple fact that to her it both is and is not a sin to have sexual relations with other women. Perhaps this inconsistency can be interpreted in the light of her religious beliefs, which for her involve a paradox between the possibility of free choice and the notion that everything is in God's hands. Çiçek also lives this paradox without choosing sides: it is both at the same time. Both are equally true.

Yet we should not make the mistake of regarding her strategy as an unconscious one. This is how she chooses to deal with her reality. To see her inconsistency as a sign of not giving these matters enough thought would thus be inaccurate, as more than anything else this would suggest a preference or need for coherence - certainly a cultural-bound concept, like all others. This apparent acceptance of living a contradictory existence is not unusual among the informants, nor is it isolated to aspects of sexuality. Thus her self-contradictory answers may be seen as consequent and rational in the context of Çiçek's understanding of free will and divine authority.

\section{Separating Different Spheres}

If Çiçek's perception of her same-sex relations as at the same time both sinful and in accordance with God's will is an important factor in her decisions, it is also true that she lives with what she perceives as a contradiction: to have same-sex relations and to be a believing and practicing Muslim. Her strategy for coping with this is to make clear distinctions between the religious sphere and the (homo)sexual one. This is in line with what both Ali and Yip depict as another frequent strategy, that of compartmentalization (Yip 2004; Ali 2006).

Çiçek believes that her relation with God is completely separate from her relations with women. Thus she tries not to mix them, because it 'is not something that God wants me to do', as she put it. Since she does not want to feel confused, she separates the areas at both the cognitive and 
the physical level. 'I try not to think about it at the same time at all', she explained. When I asked her to elaborate, she gave the practical example of the cleansing ritual after sex: 'I could never do that in the same room or in the presence of the woman I had sex with. I cannot do it when the girl is naked in bed - that's mixing it'. Here she makes a distinction by moving physically to another room or distancing herself from her object of desire. Thus her strategy of isolating the different spheres in her life from each other is performed both in the physical arena and at the level of actually guiding her thought processes.

However, even though she describes her relationship with God and her relationships with women as two separate things, they do sometimes seem to meet. At least this is how I read a statement like this one, where she jokes, self-ironically, about the problems of relationships and the way she sometimes places temporary blame on a higher power: 'In little things, if I have a quarrel with my girlfriend or the like, I sometimes feel as if God is punishing me'. Certainly, we are not always faithful to our strategies, but this way of joking can also give us a sense of the actual agency in Çiçek's choice of strategy. She makes fun of herself by pointing at something that she sees as absurd and as a weakness.

What is striking with this strategy of separation is its pragmatism, in the sense that it is based on experience and changes with circumstances, and its paradoxicality, in the sense that it is not coherent.

\section{Religious Individualism}

Why is it that this person, who surely would be condemned by many of her fellow Muslims, is at times so sure that her way of life, or at least she herself, is good in the eyes of God? How does she come to expresses such firmness in her faith?

I believe that pivotal to understanding Çiçek's choices in life is her notion of being cared for by God. At the foundation of her life experience lies a spirituality that goes beyond questions of morality. Çiçek has a personal relationship with her God: 'You always feel his presence like an angel. He does good to you', she says. She goes on to tell me about her female friends who pray constantly for forgiveness for their sins, and who have left their girlfriends because of religious reasons. This, she says, is not necessary for her, since she does not believe that it actually affects her relation with God. She is convinced that God is directing her - and in due time perhaps towards a suitable man. 
For Çiçek, her special status became clear in 2002, when she was cured of cancer. She told me this story as if it were a mystery or a secret, leaning across the table and lowering the voice to a whisper, even though we were practically alone in the room. She explained that the cancer was caused by the sadness she felt when a girlfriend left her, but God helped her get through the bad time and cured the cancer. Because of this, she became certain that God really does care for her and looks after her - that she is, in a way, chosen by God. After that experience, she described feeling 'a constant connection to God'. I find this interesting, as the story says something about the God she relates to. Even though, as far as non-heterosexuality is concerned, God is not an accepting God, it is still a forgiving, loving, and caring one. Not only did God cure her of cancer, but of a cancer caused by grief for a lost girlfriend.

One way of interpreting this aspect of Çiçek's story is to read her personal relationship to God as an expression of religious individualism. This has been shown to be an important factor in other studies as well (compare e.g. Wilcox 2002; 2003; Yip 2003; 2005). Çiçek's close bond with God gives her space to navigate more freely within the religious universe that is her religious community and its governing norms. However, it is not an individualism that is directed towards the, for her, fixed principle that is Islam. Rather, it is an individualism that has its outlet in her relationship with God. At the same time this relationship transcends the religious system: while she still believes in and adheres to the God-given complementary duality fundamental within the discourse of Islam and sexuality, her personal relation to God is more important when it comes to walking the path of a 'good' Muslim. This means that she has a personal interpretation of the image of God, while the image of Islam seems to remain intact.

\section{Conclusion}

To conclude: research on Muslims who either have an LGBTQ identity or who give expression to some kind of same-sex desire or alternative gender expression have predominantly looked at these with a will and/or need to reinterpret tradition in order to find a certain leeway with regard for example to sexuality. However, people who fall outside this group have received less attention. Through the example of Çiçek, I have shown how perceived contradictions are dealt with through other means. Among many of my informants Islam is perceived in an essentialist manner, and their Islamic tradition is not open to reinterpretation. Thus, in order to live as a 
good Muslim while at the same time having same-sex sexual and romantic relationships, negotiation must take place in other arenas.

In the case of Çiçek, her religious conviction informs the choice of sexual identity. Identifying as a heterosexual woman, even though (so far) her relations have been with women, is a fundamental premise for her success. She is able to rest in the assurance that she may be heterosexual, even though there are aspects of her life that contradict that assumption. By formulating her own definition of the concept, and by maintaining the separation between the different spheres of her life, she is able to uphold an identity as a heterosexual woman, thus adhering to a religiously motivated sexual order, and still live out her sexual desires and feelings. The way Çiçek decides/ thinks/creates herself as a heterosexual woman shows that, at one level at least, the power to define one's identity lies in one's own hands.

On the other hand, we are also governed by other people's categorizations of us and our behavior. In the example of Çiçek, this means that her sexual attraction towards individuals of the same sex forces her to find a different way to live her life as 'a good Muslim' even though at times she sees her sexual relations as sinful. Her negotiations have to do with ways of relating to the rules of her Islam, rather than a reformulation of the rules themselves. She does this mainly by means of three strategies: living with inconsistency, separating the different spheres of life, and religious individualism.

As I have tried to show, within her own context Çiçek is not subversive: she conforms to the ideal of the norm she perceives. The subversive power of her example is in the eyes of the beholder. Thus she cannot be categorized as queer in the sense of openly challenging heteronormativity, since she rather affirms this order; nonetheless she challenges my own understanding of the concept of heterosexuality.

I agree with the American literary scholar Roberto Strongman (2002), who opposes the 'western' interpretative prerogative of queer identity. He argues that a hegemonic western discourse homogenizes, and universalistically disregards, cultural and political differences in ways of viewing sexuality and gender. Strongman's arguments are important to bear in mind in discussing the context of contemporary Istanbul, where we encounter expressions and strategies that differ from stereotypic 'western' identities and/or sexual patterns. In which context these should be considered 'queer' is another question.

Moreover, an identity is constituted by various aspects of our life experiences. This involves a continuous process of negotiation among the norms 
of the surrounding society, social prerequisites, tradition, historical heritage, and the individual's own choices. Çiçek negotiates aspects of sexuality and religion in a way that enables her to construct an identity which is true to her interpretation of Islam.

Furthermore, it would be a mistake to take into account only that which is thought: as we can clearly read from the example of Çiçek, what is lived is equally important. Muslim same-sex sexual expressions as a way of life are there not because they are dictated by theological debate, but because the situation demands them. As I see it, Çiçek is dealing with a potentially disruptive situation in a way which is both creative and pragmatic. Like Çiçek, we all have the choice to negotiate and interpret our life choices and experiences. Certainly, for many, trans- and homophobia, both internal and external (from the surrounding society and from normative religious communities) are real issues; nevertheless, there are other ways of dealing with this than we may perceive at first glance. As I have shown, stigma and blessings, in this case, go hand in hand.

\section{Bibliography}

\section{Abraham, Ibrahim}

2009 'Out to get us': Queer Muslims and the Clash of Sexual Civilisations in Australia. - Contemporary Islam 3 (1), 79-97.

Ali, Kecia

2006 Sexual Ethics and Islam: Feminist Reflections on Qur'an, Hadith, and jurisprudence. Oxford: Oneworld.

\section{Ambjörnsson, Fanny}

2006 Vad är queer? Stockholm: Natur och Kultur.

Bereket, Tarik \& Barry D. Adam

2006 The Emergence of Gay Identities in Contemporary Turkey. - Sexualities 9 (2), 131-51.

\section{Boudhiba, Abdelwahab}

1998 Sexuality in Islam. London: Saqi.

af Burén, Ann

2006-2007 Queer jihad: HBT-muslimer i väst. - Svensk religionshistorisk årsskrift, 15 (8), 120-37. 


\section{Green, M. Christian \& Paul D. Numrich}

2001 Religious Perspectives on Sexuality: A Resource Guide. Chicago: Park Ridge Center.

\section{Habib, Samar}

2008 Queer-Friendly Islamic Hermeneutics. - ISIM Review 21, 30-1.

\section{Murray, Stephen O. \& Will Roscoe}

1997 Islamic Homosexualities - Culture, History, and Literature. New York: New York University Press.

\section{Murray, Stephen O.}

1997 The Will Not to Know - Islamic Accommodations of Male Homosexuality. - Stephen O. Murray \& Will Roscoe (eds), Islamic Homosexualities - Culture, History, and Literature, 14-54. New York: New York University Press.

\section{Rouhani, Farhang}

2007 Religion, Identity and Activism: Queer Muslim Diasporic Identities. - K. Browne \& J. Lim \& G. Brown (eds), Geographies of Sexualities: Theory, Practices, and Politics, 169-80. Aldershot, Hampshire: Ashgate.

\section{Strongman, Roberto}

2002 Syncretic Religion and Dissident Sexualities. - Arnaldo Cruz-Malavé (ed.) Queer Globalization: Citizenship and the Afterlife of Colonialism, 176-92. New York: New York University Press.

\section{Wilcox, Melissa M.}

2002 When Sheila's a Lesbian: Religious Individualism among Lesbian, Gay, Bisexual, and Transgender Christians. - Sociology of Religion, 63 (4), 497-513.

2003 Coming Out in Christianity. Bloomington: Indiana University Press.

2007 Outlaws or In-Laws? Queer Theory, LGBT Studies, and Religious Studies. - Journal of Homosexuality, 52 (1/2), 73-100.

Yip, Andrew K. T.

2003 The Self as the Basis of Religious Faith: Spirituality of Gay, Lesbian, and Bisexual Christians - Grace Davie \& Linda Woodhead \& Paul Heelas (eds), Predicting Religion, 135-46. Aldershot: Ashgate.

2004 Embracing Allah and Sexuality? South Asian Non-heterosexual Muslims in Britain. - P. Kumar and K. Jacobsen (eds), South Asians in the Diaspora, 294-310. Leiden: Brill.

2005 Queering Religious Texts: An Exploration of British Non-heterosexual Christians' and Muslims' Strategy of Constructing Sexuality - Affirming Hermeneutics. - Sociology 39 (1), 47-65.

2008a The Quest for Intimate/Sexual Citizenship: Lived Experiences of Lesbian and Bisexual Muslim Women. - Contemporary Islam, 2 (2), 103-29. 
2008b Researching Lesbian, Gay, and Bisexual Christians and Muslims: Some Thematic Reflections. - Sociological Research Online 13 (1), 5.

Yip, Andrew K. T. \& Amna Khalid

2010 Looking for Allah: Spiritual Quests of Queer Muslims. - Sally R. Munt \& Kath Browne \& Andrew Yip (eds), Queer Spiritual Places, 81-110. Farnham: Ashgate Publishing Ltd. 